\title{
7 \\ GOVERNANCE FOR INTEGRITY AGENCIES IN AUSTRALIA An examination of three models of influence
}

\author{
Annwyn Godwin
}

Institutional structures influence the way in which organisations and individuals interact. While the leaders of organisations may respond differently, the structures themselves can encourage or stifle collaboration, openness and innovation, and can constrain or promote independence. Leaders of integrity organisations may also have some discretion about the approach they take to their statutory responsibilities, including whether to emphasise the promotion of good behaviour or the policing of bad behaviour; there is room, at times, for integrity agencies to collaborate to get the balance right.

During my 10 years as a statutory office holder in the Merit Protection Commissioner role, I witnessed an evolution in the understanding of governance - public accountability and performance - for non-core agencies. This chapter outlines some of the major influential factors that I observed in Australia generally, and for statutory integrity agencies in particular. 
In examining governance changes, this chapter draws on my experience in the Office of the Merit Protection Commissioner (MPC) to illustrate the influence of three models promulgated since the early 2000s. The first model was presented in the Uhrig Report - after its leader, John Uhrig - which was commissioned by the Australian Government to review the corporate governance of Commonwealth authorities. The second model was outlined by Jocelyne Bourgon, a former head of the Canadian civil service, in her keynote address to the Institute of Public Administration Australia (IPAA) national conference in Sydney in June 2008. The third model was presented in a paper by Maryantonett Flumian, another former senior Canadian public servant and president of the Public Governance Exchange (PGEx), at the Public Sector Governance Conference hosted by the Australian Institute of Company Directors in October 2009.

My own experience, drawing on these models, is that public sector governance arrangements, including for integrity organisations, continue to evolve. While such agencies require a considerable degree of independence and autonomy, it is not easy to categorise them or apply a common or fixed approach to their accountability or management arrangements for optimising performance.

\section{The Uhrig Report}

Uhrig completed his Review of Corporate Governance of Statutory Authorities and Office Holders in 2003. It was influential at the time in attempting to develop a broad template of governance principles for statutory agencies that drew upon best-practice models in the public and private sectors.

The report's context was the financial management reforms enacted in the 1990s. At the time there was limited consideration of the implications of the significant machinery of government $(\mathrm{MoG})$ changes that occurred in 1987 and the expansion of statutory authorities under new public management (NPM) reforms. The 1987 changes included the establishment of mega-departments and 'portfolios' that grouped agencies (including statutory authorities) under 'portfolio ministers' and gave the 'portfolio department' implicit responsibility for coordinating portfolio budgets and policy advice. The administrative, reporting and accountability arrangements to parliament changed as a result of the creation of the roles of assistant ministers and parliamentary secretaries to support portfolio ministers. As John Nethercote noted in 1999: 
there has continued to be considerable organisational change within portfolios, especially through hiving off, corporatisation and privatisation, for instance, by creation of Centrelink, based on the regional networks of the departments of Social Security and Employment, Education and Training, or establishment of bodies such as the Civil Aviation Safety Authority and the Australian Maritime Safety Authority within the Transport Department. (Nethercote 1999)

The establishment of a wide range of statutory organisations over this period was not just a political response to the issues of the day, but also a response to broader developments in public sector management. These developments included NPM's focus on results including through wider principal-agent arrangements, the new role of regulation that emerged with commercialisation, privatisation and competition policy, and increasing interest in 'integrity' and the oversight of public sector governance values, especially following NPM's devolution of authority.

The statutory bodies, encompassing regulatory, service delivery and government oversight functions, used a range of governance structures. Most were subject to the Commonwealth Authorities and Companies Act 1997 for the purposes of formal financial management and accountability and some were subject to the Public Service Act 1999.

The key recommendations of the Uhrig Report may be summarised as:

1. a firmer and more consistent approach to accountability with two main governance templates, one being via an executive board the other via a single accountable CEO, where any board would be advisory only

2. notwithstanding statutory independence, some recalibration of the line of accountability through the minister to the parliament by having a ministerial statement of expectation of how the authority is to exercise its responsibilities and a corresponding statement of intent by the authority

3. a firmer role for the 'portfolio' secretary of the relevant department in advising on appointments and coordinating the agencies within the portfolio.

I regarded the Uhrig review as having led, at least for a short while, to an alignment at the highest level between management rhetoric and management practice, in terms of a stronger focus on governance 
arrangements and management accountability. I held a senior departmental management position in 2003 and the mantra of 'let the managers manage' felt real, including the expectation of being held to account. This meant senior managers needed sound evidence to support decision-making and could be expected to demonstrate this if called to explain. It may of course be coincidental that this period was also when a wide range of accountability reforms came to fruition including, for example, the charter of budget honesty (1998), the integrated accrual accounting framework (1999-2000) and the consolidated Commonwealth Procurement Guidelines (2004).

One impact of these developments was increasing standards of public accountability for officials rather than ministers only. Dr Derek Drinkwater drew upon his experiences at the Australian Public Service Commission (APSC) and in the department of the Senate when researching his paper on parliamentary scrutiny of the Australian Public Service (APS). He reported that since 1996 'more and more, senior public servants at the table, rather than ministers, were being required to answer questions and explain decisions, and to do so at an unprecedented degree' (Drinkwater 2015: 61). This trend was arguably underway for much longer, particularly since the strengthening role of parliamentary committees and their focus on questioning officials. The shift was to some extent inevitable, of course, for statutory officers with statutory independence from ministerial direction who must be held accountable directly for the exercise of those responsibilities.

In many respects, Uhrig brought to a head a growing disconnect between public sector managers' accountability and the traditional Westminster ministerial accountability to parliament. Uhrig, however, applied private sector practice to the issue in his terminology and focus on CEOs and boards and, arguably, he did not appreciate sufficiently the public sector environment. But he exposed a potential accountability vacuum and suggested a particular way of addressing it. This involved the exchange of statements of expectations and intent between ministers and the statutory authorities 'that identified agreed outcomes and priorities without compromising the authorities' statutory independence'.

Another grey area concerned responsibility for appointments to individual statutory officer roles. Section 19 of the Public Service Act specifically prohibits a minister from directing an agency head with regard to APS staffing decisions. From its beginnings, selection into the APS was consciously designed for people to compete and be assessed on their ability 
on the basis of the merit principle. The Public Service Act includes explicitly a provision that employment decisions be based on merit, but this does not apply to the employment of agency heads. The prime minister appoints departmental secretaries (following a report by the secretary of the Prime Minister's Department) and ministers appoint the heads of other agencies (in practice, the decisions are subject to cabinet endorsement); there is no formal statutory requirement to consider or apply merit.

Uhrig recommended that portfolio secretaries advise ministers on the appointment of statutory office holders in the portfolio. While this would not enforce a merit-based approach, it would inform ministers of the relative merit of those considered by the portfolio secretary, while leaving the final decision to ministers. While this recommendation was generally implemented, it is not clear that it was widely influential in the final decision. In early 2008, however, the APSC published Merit and Transparency: Merit-Based Selection of APS Agency Heads and APS Statutory Office Holders (APSC 2012), a policy document agreed by the then government.

This document affirmed merit as a basis for selection of most APS agency heads and other statutory office holders working in, or in conjunction with, APS agencies, giving formal authority to portfolio secretaries in their advising role in consultation with the Public Service Commissioner. There were exceptions to the application of the policy, notably with regard to the APS Commissioner, the Commissioner of Taxation, the Auditor-General, the CEO of the (then) Australian Customs Service and the Australian Statistician. These positions, of a similar status to portfolio secretaries, had an expectation of appointment on merit (in the case of the auditor-general, consultation with the relevant parliamentary committee is required).

In the context of governance and Uhrig, this policy document was another recognition of the changing nature of the relationships and accountabilities between ministers and portfolio secretaries. For the first time the roles of a secretary, the APS Commissioner and the minister in a statutory appointment process were explicitly identified. Importantly, portfolio secretaries have responsibility for the processes of appointments within their portfolios and for advising the minister of the recommendations from those processes. While there is an expectation that the minister will accept those recommendations, there are important exception clauses where the minister (and the government) can override the recommendations. 
These developments, influenced by Uhrig, did not settle other grey areas that have emerged over the years in the relationship between ministers and senior officials. The other key trend has been the growth in numbers and influence of ministerial staff outside the public service. After attempts by the APSC to clarify the respective roles of public servants and ministerial staff (APSC 2003, 2005), in 2008 the then government introduced a formal (but not statutory) code of conduct for ministerial staff that includes the provision the APSC had previously articulated that such staff do not have the power to direct APS staff or make decisions: such power lies exclusively with ministers and public servants. That code (slightly amended) still applies, though its title has changed to Statement of Standards for Ministerial Staff. ${ }^{1}$

\section{Uhrig and the Office of the Merit Protection Commissioner}

Uhrig's terms of reference 'required an examination of structures for good governance, including relationships between statutory authorities and the responsible Minister, the Parliament and the public, including business' (Uhrig 2003: 1). Importantly, Uhrig's report attempted to place some boundaries and insert a consistent nomenclature around the plethora of authorities and structures that had flourished. Once departments of state and executive agencies were accounted for, the term 'statutory authority' was a convenient way to cover the remaining structures created by law. While not a way of classifying different statutory authorities, the report defined the following selection of terms (more than one term may apply to the same organisation):

- Department of state

A department created by the Administrative Arrangements Order made by the Governor-General.

- Executive agency

An agency established under section 65 of the Public Service Act 1999.

1 Statement of Ministerial Standards available at www.smos.gov.au/statement-standardsministerial-staff. 


\section{- Statutory authority}

A public sector entity created by a specific law of the Commonwealth. For the purposes of this report the term includes a statutory agency having statutory office holders.

\section{- Statutory agency}

A body or group of positions declared by an Act to be a statutory agency for the purposes of the Public Service Act 1999.

\section{- Regulatory authorities}

Those entities that administer legislation on behalf of government to regulate the behaviour of individuals and/or organisations.

\section{- Commission}

A statutory authority with a full-time executive management structure that is directly accountable to a Minister. (Uhrig 2003: 121-24)

Likewise, Uhrig defined office holders as:

those persons appointed to statutory positions in the governance structure of a statutory authority. Depending on an authority's particular structure, these positions would include the CEO or managing director, commissioners and members of a board of directors.

The role of a statutory office holder is principally to implement legislation. Given how difficult it usually is to remove an officer from office once appointed, it is a position of considerable trust and stewardship.

For example, the office of the Merit Protection Commissioner is one of only two individual offices specifically named in the Public Service Act (the Public Service Commissioner being the other). My appointment was made via a national and open merit-selection process. As required under sections 61 and 62 of the Australian Constitution, my name was put forward to the executive council for appointment by the governor-general.

The independence of the role is enshrined in the legislation and the normal five-year term safeguards against political or other interference as it is longer than the usual term (around three years) of an Australian federal government. 
Section 54 of the Public Service Act states:

Removal from Office

1. The Governor-General may remove the Merit Protection Commissioner from the office if each House of the Parliament, in the same session of the Parliament, presents an address to the Governor-General praying for the removal of the Merit Protection Commissioner on the grounds of misbehaviour or physical or mental incapacity.

2. The Governor-General must remove the Merit Protection Commissioner from the office if the Merit Protection Commissioner does any of the following:

a. becomes bankrupt;

b. applies to take the benefit of any law for the relief of bankrupt or insolvent debtors;

c. compounds with his or her creditors;

d. assigns his or her remuneration for the benefit of his or her creditors.

The terms of the appointment are designed to reinforce the Merit Protection Commissioner as free of influence and able to uphold public sector governance values whilst fulfilling the statutory requirements. Consistent with the APSC's Merit and Transparency policy, the final decision-maker regarding the appointment is at arm's length from the independent recommendations put forward as a result of the selection process.

\section{Post-Uhrig work on governance}

Australian governance structures have evolved considerably since the Uhrig Report. Among the criticisms of the report and its private sector focus was its failure to clarify whether and when statutory authorities should be under the Public Service Act and which financial management and accountability legislation should apply (the Financial Management and Accountability Act 1997 or the Commonwealth Authorities and Companies Act 1997). The Department of Finance issued some guidance on these matters in 2005, and a more substantial internal review in 2012 (the Commonwealth Financial Accountability Review (CFAR)) recommended action that led to the replacement of both financial management laws with the Public Governance, Performance 
and Accountability Act 2013 (PGPA). The PGPA Act and its definition of Commonwealth entities for financial purposes had flow-on effects for the governance structures of entities and, in particular, Finance's issuing of guidance about the establishment of new entities.

While Finance's definitional terminology in its policy guidance on governance structures has some similarities to Uhrig's, it has been simplified and sharpened; for example, 'A statutory authority is a generic term for an Australian Government body established through legislation for a public purpose. This can include a body headed by, or comprising, an office holder, a commission or a governing board'. ${ }^{2}$

Finance guidance now includes measures relating to the circumstances in which alternative organisational structures may be required. Through an assessment tool, it has identified seven considerations when establishing an alternative governance structure. These are summarised as, does the activity:

1. require enabling legislation which cannot be altered without parliamentary authorisation

2. involve exercising coercive (enforcement) or regulatory powers usually for a specific field or industry and may include regulatory fees, imposing penalties, conducting investigations and/or compelling production of evidence

3. have core policy (and/or non-commercial) government functions, as this may be better served within an existing non-corporate Commonwealth entity

4. have a commercial focus

5. need to hold money outside the Commonwealth

6. necessitate a governing board or multi-member accountable authority

7. require a level of independence, based on an assessment of risk.

Finance goes on to acknowledge that 'It is enabling legislation that provides the level of independence of Commonwealth entities, not the type of entity ... Ultimately it is the level of risk in undertaking the activity that will dictate the level of independence for the body. ${ }^{3}$

2 Available at www.finance.gov.au/about-us/glossary/governance/term-statutory-authority.

3 Finance advice on governance structures is available at www.finance.gov.au/government/managingcommonwealth-resources/structure-australian-government-public-sector/commonwealth-governancestructures-policy-governance-policy. 
Some public servants and commentators considered the Uhrig Report too private sector-oriented and too narrow in its understanding of the range of government functions and possible structures. The two main templates for accountability - via a board or a single CEO point - held little flexibility to assimilate non-core functions and political circumstances. While it exposed gaps in the existing system, the recommended solutions didn't always work as expected. The seeds of Uhrig can be seen, nonetheless, in the more flexible but coherent PGPA Act following CFAR, and its principles-based approach provided a new paradigm for governance.

\section{Jocelyne Bourgon and Maryantonett Flumian}

The second and third models that had a major influence on me in my role as Merit Protection Commissioner were both from Canada. Bourgon's model was enunciated in her 2008 paper 'Future of the public service: a search for new balance' and further developed in her collaborative book A New Synthesis for Public Administration (2011), which is based on seven case studies.

Bourgon provides an evolutionary framework to make sense of developments in public administration, including through NPM and subsequent reforms. She first acknowledges the origins and contribution of public administration in democratic governments:

Many of our public institutions were born in the latter part of the 19th century and early 20th century; a period characterised by the industrial revolution, the emergence of bureaucracies in democratic societies and the influence of scientific management.

Public sector organisations were expected to perform predictable tasks under prescribed rules. The power structure was top down and hierarchical. Rigorous controls ensured performance and accountability for delegated authorities. (Bourgon 2008: 5)

The structures of public accountability and performance in Australia (and Bourgon's Canada) are inherited from the United Kingdom. The Westminster parent gave its colonial children institutions based on the rule of law, respect for democracy, due process, transparency and accountability. 
Bourgon's model draws upon the broad base of conceptual thinking that challenged this 'classic model' of public accountability, including NPM's focus on accountability for results and subsequent emphasis on whole-of-government and networking beyond government. Christopher Hood's 1990 article 'De-Sir Humphreyfying the Westminster model of bureaucracy: a new style of governance?' was followed by another thought piece on the intellectual provenance of NPM (Hood 1991). Rod Rhodes wrote about policy networks, reflexivity and accountability in the late 1990s (Rhodes 1997) and Stephen Osborne argued in 2006 that NPM was a transitory phase in public administration (PA) before it emerged as new public governance (NPG). Bourgon constructively links these emerging ideas of the late 1990s and early 2000s in her framework; she doesn't categorise traditional PA, NPM and NPG but rather 'synthesises' (her term) them in a modern and more integrated approach. She offers jurisdictions at different stages of development or facing different challenges the flexibility to move between different paradigms and to balance approaches to suit their circumstances. Figure 7.1 illustrates Bourgon's 'synthesis' concept.

\section{Public Sector Reforms}

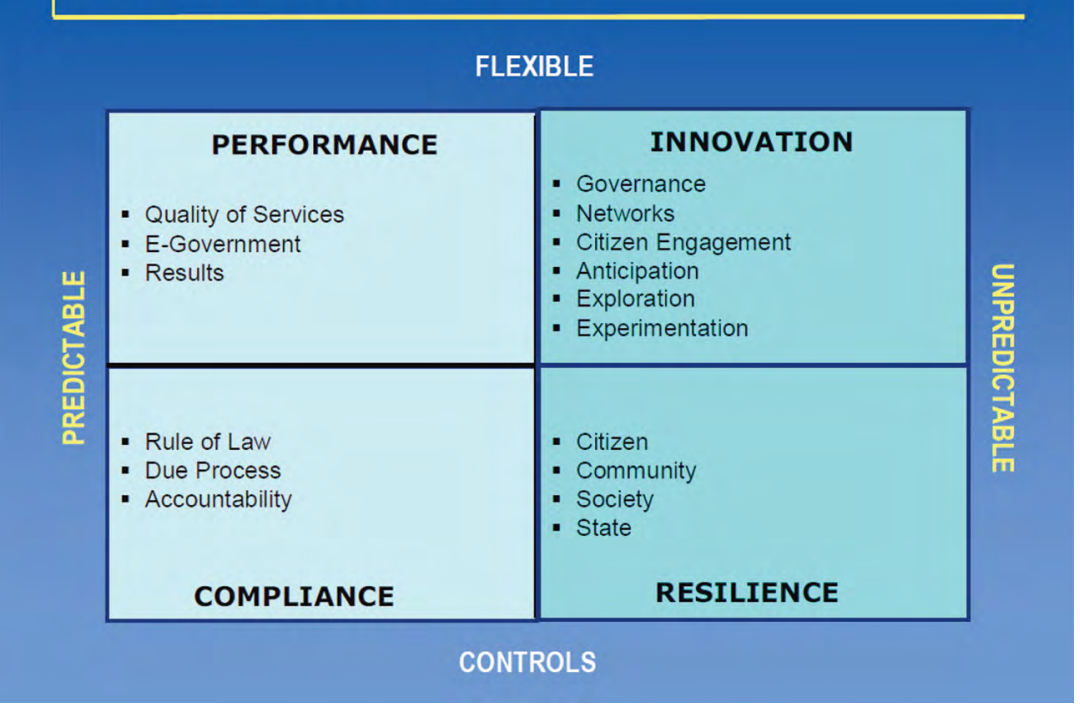

Figure 7.1. Categorising public sector reforms

Source. Bourgon 2008 
She notes that 'A combination of vertical accountability for the exercise of delegated authority and of network management improves the capacity of the public sector to achieve system-wides results' (Bourgon 2008). Bourgon's model offers a whole-of-government approach to governance - acknowledging all the competing parts - rather than identifying any single approach that may be optimal to a specific function of government; at the same time, she recognises the continuing value of the traditional emphasis on compliance and NPM's emphasis on performance.

Like the UK and Canadian models, Australia's public sector institutions were established before the availability of the internet and before artificial intelligence. Our structures, expectations and accountability mechanisms were based on old paradigms of bureaucracy. In the early 2000s, at the time when Bourgon presented her synthesis, the emerging governance questions were:

1. Are the current hierarchical and lineal structures flexible enough to address evolving community and parliamentary expectations?

2. If not, how can we structurally encourage tailored and immediate responses to complex and interconnected issues?

This was a time when the APS trialled a variety of new practices in an attempt to dismantle siloed responses to 'wicked problems' ${ }^{4}$ including, for example, how to encourage meaningful cross-agency collaboration when one agency supplied the resources and another was accountable for the outcomes. Bourgon's view of the evolving nature of management provided new ways of thinking about the needs of the public sector and the range of potential responses. Her ideas exposed the inherent tension within modern management of traditional accountability structures for non-hierarchical, non-traditional relationships.

While these ideas did not have a particular impact on me as the Merit Protection Commissioner, they did influence me and many other senior Australian public servants about the way we worked across and beyond government.

In 2009, Maryantonett Flumian's outlined 'The new reality of "distributed governance", which she described as having three main dynamics (Flumian 2009):

4 www.apsc.gov.au/publications-and-media/archive/publications-archive/tackling-wicked-problems 
1. governments have been transforming to accommodate the realities of a faster paced, networked and globalised world

2. redistribution of the functions of government from traditional command-and-control core bureaucracies to public models of governance distributed across a variety of factors based on performance

3. a significant shift in the organisational design of public institutions and a significant increase in the number, size and significance of organisations along a much longer governance continuum.

She summarised the impact, both positive and negative, of these on governance, as shown in Table 7.1.

Table 7.1. The impact of 'distributed governance'

\begin{tabular}{|l|l|}
\hline \multicolumn{2}{|c|}{ Governance impacts } \\
\hline Intended & Unintended \\
\hline Devolution & Less direct relationship with citizens \\
\hline Increase in distributed governance & Role confusion / mandate diffusion \\
\hline Deregulation & Decreased accountability capacity \\
\hline Re-centralisation & Who's got the ball \\
\hline Redefined relationships & Indirect accountability \\
\hline Clarified mandates / performance targets & Increased importance of departmental silos \\
\hline Effectiveness? & Effectiveness? \\
\hline
\end{tabular}

Source. Flumian 2009

Flumian's work was a natural and logical extension of Bourgon's, but with more specific relevance to the Merit Protection Commissioner's role and accountability. The evolving nature of the operating environment led to shifts in formal roles and accountability methods. Agencies realised that the traditional arrangements established for highly centralised and hierarchical models didn't reflect the use of alternative organisational models and degrees of independence. This led to a rethinking of how different agencies interact along a governance continuum; in particular, the need for a conceptual model to capture and map organisational independence and institutional control across the public spectrum, from the centre to the most autonomous models. Even within and along the continuum, however, roles and relationships may vary and overlap. Flumian's model is summarised in Figures 7.2, 7.3 and 7.4. 


\section{Governance impacts}

\begin{tabular}{|c|c|}
\hline Intended & Unintended \\
\hline $\begin{array}{l}\text { - Devolution } \\
\text { - Increase in distributed } \\
\text { governance } \\
\text { - Deregulation } \\
\text { - Re-centralization } \\
\text { - Redefined relationships } \\
\text { - Clarified } \\
\text { mandates/performance } \\
\text { targets } \\
\text { - Effectiveness? }\end{array}$ & $\begin{array}{l}\text { - Less direct relationship } \\
\text { with citizens } \\
\text { - Role confusion/mandate } \\
\text { diffusion } \\
\text { - Decreased } \\
\text { accountability capacity } \\
\text { - Who's got the ball? } \\
\text { - Indirect accountability } \\
\text { - Increased importance of } \\
\text { departmental silos } \\
\text { - Effectiveness? }\end{array}$ \\
\hline
\end{tabular}

Figure 7.2. Traditional hierarchical and contemporary accountability relationships

Source. Flumian 2009

Public

Legislature

Executive

Minister

Department

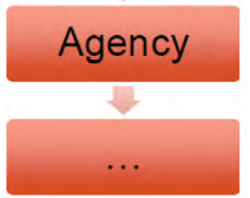

...traditional

Figure 7.3. Institutional control - operational autonomy continuum Source. Flumian 2009 


\section{Functions place organizations along the Continuum}
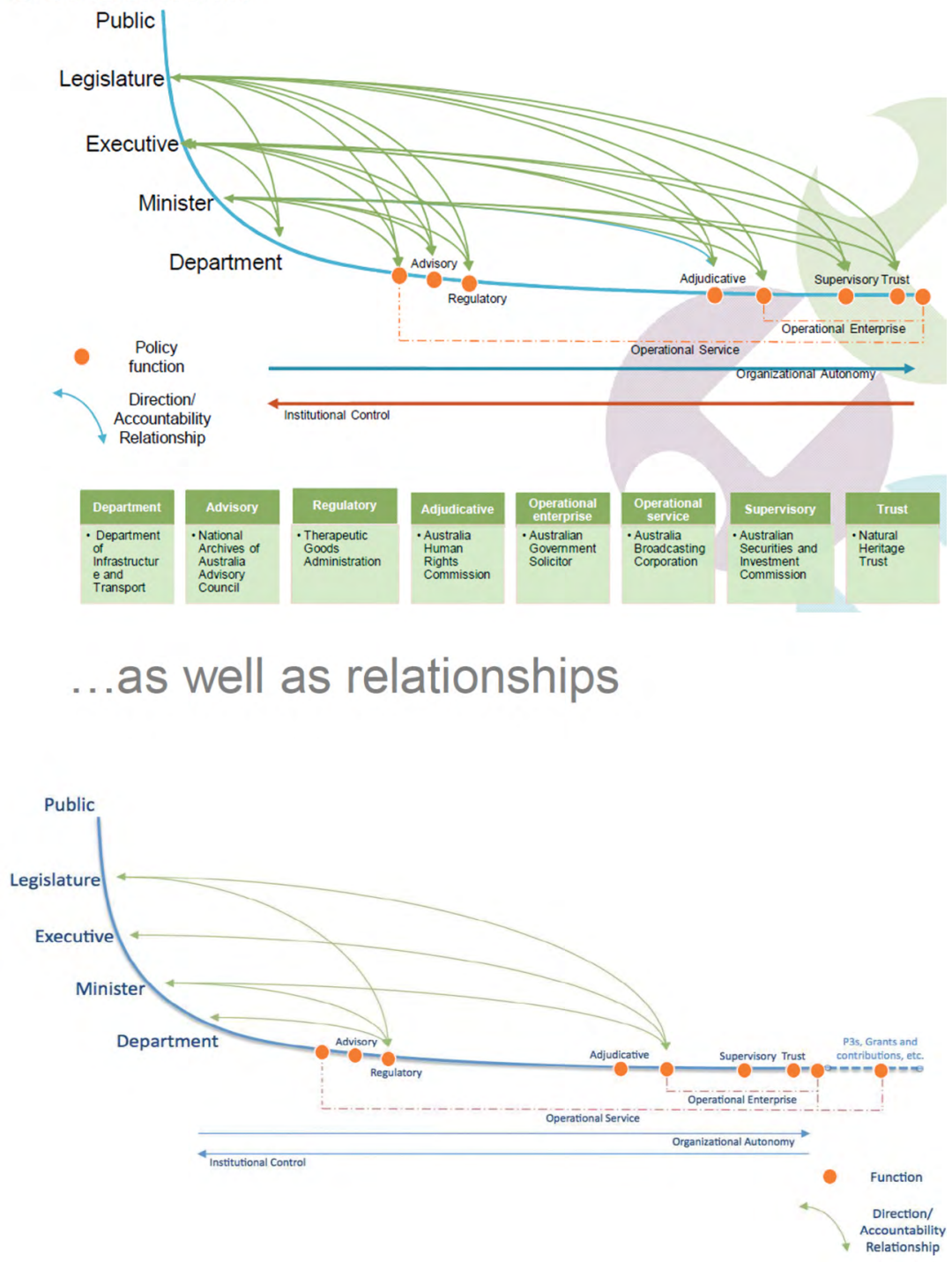

Figure 7.4. Mapping organisations' functions and relationships to the continuum

Source. Flumian 2009 
This model brought together the thinking behind the Uhrig Report and subsequent Finance guidance about the establishment of different structures, and Bourgon's ideas about structures evolving to meet new requirements. Flumian's framework combined these elements, offering a way to map and integrate different structures in interconnected systems.

While Flumian's model made intuitive sense, it didn't neatly map to the wide range of Australian public sector organisational forms (see Table 7.2). While Flumian's operational service and enterprise categories may be a matter of interpretation (corresponding broadly to service delivery agencies and government business enterprises), there was greater difficulty with mapping Australian structures to her regulatory, adjudicative and supervisory categories. In particular, Australia's 'integrity bodies' cover a wide range of organisational forms and functions that potentially overlap several of Flumian's categories (Table 7.3 identifies the multiple roles of a selection of integrity bodies).

\section{Table 7.2. Mapping the Flumian model to Australian practice}

\begin{tabular}{|l|l|}
\hline Flumian model & Australian translation \\
\hline Ministry: traditional generalist department & Departments (central and line) \\
\hline $\begin{array}{l}\text { Advisory: publicly provides advice } \\
\text { to government }\end{array}$ & $\begin{array}{l}\text { Special research and policy-advising } \\
\text { authorities (statutory bodies) }\end{array}$ \\
\hline $\begin{array}{l}\text { Regulatory: establishes and/or enforces } \\
\text { rules of conduct in a particular sector of } \\
\text { activity against obligations set out in existing } \\
\text { statutes and/or regulations }\end{array}$ & $\begin{array}{l}\text { Regulatory bodies, integrity bodies, } \\
\text { independent commissions and } \\
\text { tribunals }\end{array}$ \\
\hline $\begin{array}{l}\text { Adjudicative: renders impartial quasi-judicial } \\
\text { decisions to resolve disputes }\end{array}$ & \\
\cline { 1 - 2 } $\begin{array}{l}\text { Operational service: delivers programs and } \\
\text { services to the public in a primarily non- } \\
\text { commercial manner within a well-defined } \\
\text { policy framework determined outside the } \\
\text { organisation itself }\end{array}$ & $\begin{array}{l}\text { Executive agencies and service delivery } \\
\text { authorities (also, often departments) }\end{array}$ \\
\hline $\begin{array}{l}\text { Operational enterprise: sells programs } \\
\text { and services to the public in a primarily } \\
\text { commercial manner }\end{array}$ & $\begin{array}{l}\text { Government business enterprises } \\
\text { and other commercial units }\end{array}$ \\
\cline { 1 - 2 } $\begin{array}{l}\text { Supervisory: impartially oversees activities } \\
\text { on behalf of another entity with authority over } \\
\text { those activities and reports on its findings }\end{array}$ & $\begin{array}{l}\text { Integrity bodies, independent } \\
\text { commissions }\end{array}$ \\
\hline $\begin{array}{l}\text { Relationship trust: invests or otherwise } \\
\text { administers funds on behalf of the public, } \\
\text { other groups and entities. }\end{array}$ & $\begin{array}{l}\text { Non-government organisation (NGO) } \\
\text { bodies linked with government }\end{array}$ \\
\hline
\end{tabular}

Source. Flumian 2009 and author's assessment 
Under Flumian's model, integrity agencies, including the Merit Protection Commissioner, lie towards the independence end of the spectrum, though there remain uncertainties about the degree of independence and operational autonomy of different integrity agencies.

\section{Australian integrity agencies and the Integrity Agencies Group}

The collective idea of 'integrity organisations' is not institutionalised at the federal level, though the term has been used by some state governments (e.g. Western Australia). Senator John Faulkner as Special Minister for State, used the term in a ministerial speech in 2008 when he said:

One of our first steps was to bring under a single minister integrity agencies across the Commonwealth such as the ANAO [Australian National Audit Office], the Inspector-General of Intelligence and Security, the ombudsmen [sic], the Public Service Commissioner, the Archives and the like. (Faulkner 2008)

With this as the context, the then Public Service Commissioner, Lynelle Briggs established the Integrity Agencies Group (IAG). The original membership included the relevant statutory office holders that focus on integrity-related matters from within the portfolio of Prime Minister and Cabinet. The goal was to support a 'joined-up' approach to whole-ofAPS integrity-related issues within the portfolio. As agencies moved in and out of the portfolio, so too did the membership. For example, the Australian Electoral Commissioner, while upholding the integrity of the electoral process and thereby the legitimacy of government, is no longer an IAG member; however, when the Office of the Australian Information Commissioner was created, the three commissioners - Privacy, Freedom of Information and Australian Information - became members.

With subsequent machinery of government, policy and legislative changes and a new APS Commissioner, the IAG evolved to reflect a clearer understanding of the integrity framework, though there is no longer a minister with explicit responsibility for integrity organisations. IAG membership and its role have varied over time and are no longer based on the portfolio of Prime Minister and Cabinet. The nature of the group changed significantly around 2012 with the extension of jurisdictional 
coverage of the Australian Commission for Law Enforcement Integrity (ACLEI) to include specific agencies that employ staff under the Public Service Act. ACLEI joined the IAG around this time.

Under APS Commissioner Stephen Sedgwick, the IAG responded to two cases of integrity organisation inquiries: the Home Insulation Program inquiry by the Australian National Audit Office and specific activity that ACLEI identified involving Australian Customs Service employees at Sydney international airport. The IAG recognised the intrinsic links between culture, leadership and behaviour and how a tolerance of lowlevel indiscretions and general misconduct can, and does, influence an organisation's (and the APS's) overall integrity risk profile.

The overlapping roles of IAG members were recognised as part of an education-to-enforcement continuum for integrity in the APS. As Sedgwick stated before the ACLEI Committee in 2014:

One of the things we have learned out of the experience that ACLEI has had ... has been the availability of forensic skills to investigate quite complex issues and that has been valuable to resolving those matters. An environment in which you have a modulated series of responses, for example, makes sense in terms of the relationship between the risk that is being borne and the costs that are involved. We have a number of agencies that operate in this space ... We [the APSC] promote the values and the employment principles, the ethical framework and the code of conduct ... We work at one end of the spectrum, if you like; ACLEI works at the other - ACLEI or the AFP [Australian Federal Police], depending on the nature of the issues. (Parliamentary Joint Committee on the Australian Commission for Law Enforcement Integrity 2014)

The education-enforcement continuum is just that, a risk-based sliding scale. It guides organisations to identify the appropriate response to a situation at both inter- and intra-agency levels. For example, at an internal level, when the Merit Protection Commissioner reviews agency decisions on code of conduct breaches and makes a recommendation, there is the potential for:

- an education intervention - to help a public servant learn from the outcome and hopefully ensure he or she is unlikely to repeat the mistake or

- an enforcement intervention - to punish wrongdoing as an example to others, with the downside risk of creating a vexatious employee with attitude! 
In my experience as Merit Protection Commissioner, the two extremes complete education or complete enforcement - are not where most effort is spent. Rather, an approach resting between the two is used. Depending on the intervention, this approach tries to engage the person concerned as a positive partner, not as a negative influencer. The intent is to have as many individuals and teams working with, not against, the system. This reduces workload, creates a peer cohort of support and allows the Merit Protection Commissioner to focus on areas of high and serious risk that require enforcement. Again, the approach is to target the intervention and the sanction.

In the APS environment, the overlapping and complementary roles of specialist integrity agencies have been promoted as a basis for a strong and appropriate response to upholding integrity in our specific environment. The interagency continuum framework enabled targeted and escalating interventions as appropriate. The IAG played a significant role in providing a level of assurance that a multi-pronged approach to the APS integrity framework is indeed integrated. Under this umbrella, information and insight has been shared and the experience, knowledge and contribution of all members to the integrity framework has been recognised and valued. The IAG has no formal role or status and its contribution is based on the assumed goodwill and understanding of the principal members.

Considering the roles of Australian integrity agencies along the educationenforcement continuum (educative, regulatory, adjudicative, enforcement) provides insight into why it is difficult to map their multipurpose roles strictly against the Flumian model (see Table 7.3).

For example, the APSC's role in encouraging the embedding of the APS Values as a means of supporting a positive workplace culture is at the education end of the spectrum, and ACLEI, with its forensic fraud investigations, is an example of the enforcement end. The Merit Protection Commissioner and most other integrity agencies are bridges somewhere in between. All are focused on learning and preventing the recurrence of inappropriate behaviour. 
DESIGNING GOVERNANCE STRUCTURES FOR PERFORMANCE AND ACCOUNTABILITY

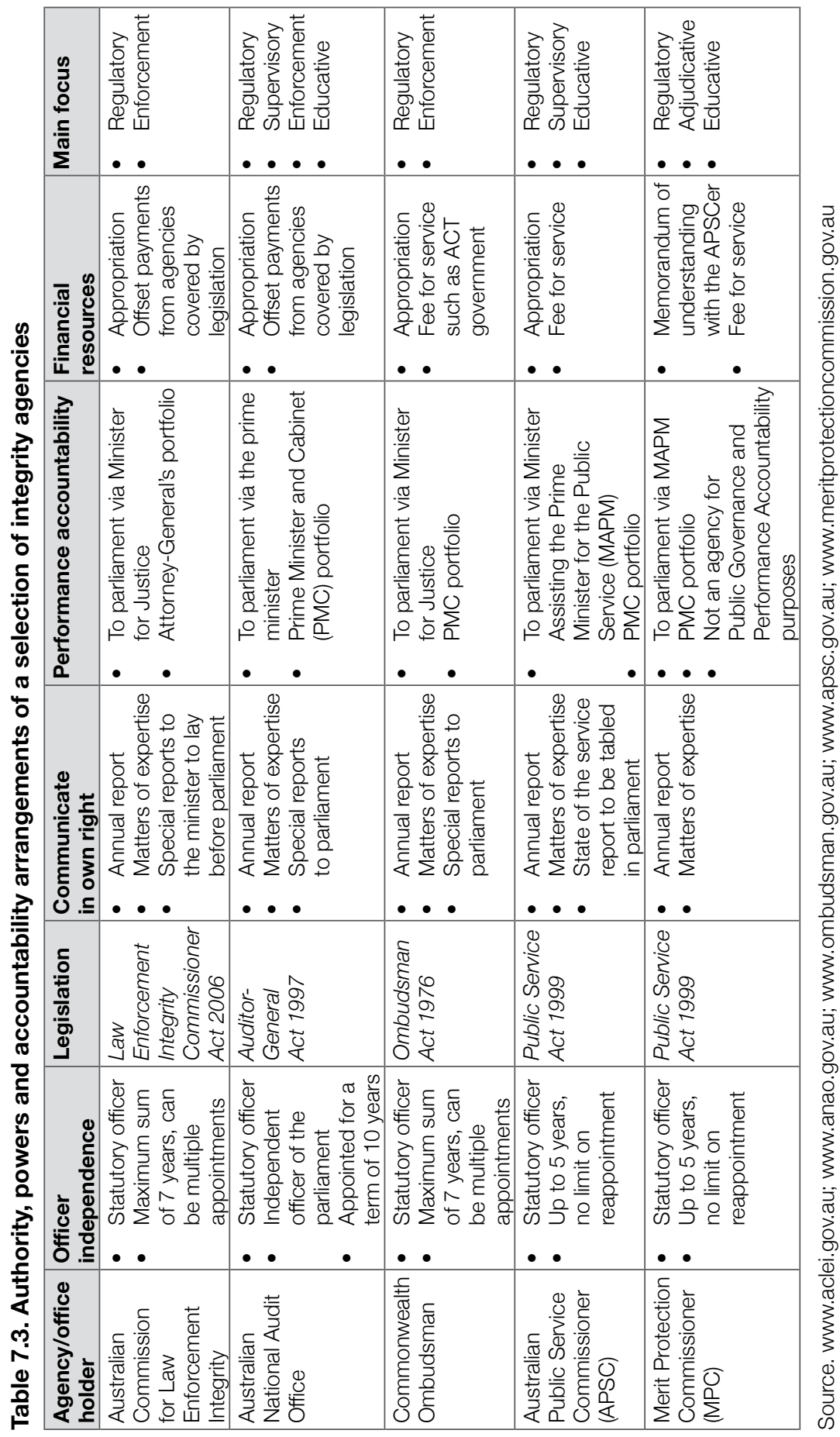


Mapped against the Flumian model, the Australian integrity agencies are statutory agencies under the Public Service Act and tend to clump around the 'regulatory' and 'adjudicative' sections of the curve, though some may be categorised under Flumian's model as 'supervisory'. Even ACLEI seems to fall into the regulatory and adjudicative sections of the spectrum as it must employ staff under the Public Service Act and cannot prosecute under its own legislation. As it must work in tandem with a relevant law enforcement agency to lay charges of criminal activity, it is unclear to me how operationally autonomous it is when mapped to Flumian's model.

The Flumian regulation and adjudicative categories tend to have a particular governance style; for example, focusing on policy autonomy, the leader's term of appointment, their specific statute and legal personality, as well as having a governing board. This may reflect Flumian's Canadian heritage and public service experience. The dimensions of her categorisation are also linear in nature and assume a level of structural discipline that may work well in theory but not necessarily in practice.

Independence is a relative term - independence from whom or to do what? There may be value in developing a public administration continuum that maps degrees of autonomy and control. For example, dimensions could identify how much control or autonomy an organisation has in practice to make budget and financial decisions, appoint staff and manage personnel, conduct research and release communications.

From my experience as the Merit Protection Commissioner, an independent complaint/investigation-type agency also faces certain underlying strategic issues, including:

- providing credible assurance on the integrity and fairness of decisionmaking while simultaneously exposing endemic issues to be addressed

- building relationships and networks to influence policy change while retaining impartiality and independence.

To these I would add the administrative issue of improving costeffectiveness and reducing red tape while ensuring the legality of due process.

There is no right or wrong approach to balancing these issues; achieving the balance is a result of leadership, vision and judgement depending on the evidence available at the time. My experience as a commissioner revealed to me that balancing the above is difficult in a media savvy, 
fast-paced environment where the prized quality of a timely response can come at the expense of proper investigation. It can also be difficult to maintain a media or other profile without being perceived as 'crying wolf' over every incident; picking the cases not to promulgate is more difficult than it may seem.

\section{Conclusion}

Having had the luxury and privilege of two terms in the statutory role as Merit Protection Commissioner, it is easy to observe through Uhrig, Bourgon and Flumian that requirements and expectations are continuing to evolve. In Australia, the role of integrity agencies is not easy to categorise and new dimensions may assist in reflecting the complexity and sophistication of our environment.

\section{Acknowledgements}

I would like to acknowledge the assistance of the staff made available to the Office of the Merit Protection Commissioner and Ms Lorna Kunz, in particular, in the preparation of the original presentation. I would also like to acknowledge and thank Professor Andrew Podger for his assistance in translating the presentation into a chapter for publication.

\section{References}

Australian Public Service Commission (APSC) 2003, APS Values and Code of Conduct in Practice: A Guide to Official Conduct for APS Employees and Agency Heads, www.apsc.gov.au/aps-values-and-code-of-conduct-practice.

2005, Supporting Ministers - Upholding the Values, www.apsc.gov.au/ supporting-ministers-upholding-values.

— 2012, Merit and Transparency: Merit-Based Selection of APS Agency Heads and APS Statutory Office Holders, 4th edn, Australian Government, www. apsc.gov.au/sites/default/files/Merit-and-transparency.pdf.

Bourgon, J 2008, 'Future of the public service: a search for new balance', key note address, Institute of Public Administration Australia (IPAA) National Conference, Sydney, June, doi.org/10.1111/j.1467-8500.2008.00597.x. 
2011, A New Synthesis of Public Administration: Serving in the 21st Century, Kingston School of Policy Studies and McGill-Queens University Press.

Commonwealth of Australia 1998, Charter of Public Honesty Act 1998, www.legislation.gov.au/Details/C2020C00126.

Department of Finance 2004, Commonwealth Procurement Guidelines, www. legislation.gov.au/Details/C2010L00022.

Drinkwater, D 2015, 'Parliamentary scrutiny of the Australian Public Service', in J Wanna, EA Lindquist \& P Marshall (eds), New Accountabilities, New Challenges, ANU Press, Canberra, p 61, doi.org/10.22459/NANC.04. 2015.03 .

Faulkner, J. 2008, 'Ministerial Statements: Restoring integrity to government', Speech in Journals of the Senate, No. 52, 4 Dec, parlinfo.aph.gov.au/parlInfo/ genpdf/chamber/hansards/2008-12-04/0206/hansard_frag.pdf;fileType= application\%2Fpdf.

Flumian, M 2009, 'Global perspective on public sector governance: the governance continuum as a dynamic tool', conference paper, Public Sector Governance Conference, Australian Institute of Company Directors, Canberra, October, slide 5 .

Hood, C 1990, 'De-Sir Humphreyfying the Westminster model of bureaucracy: a new style of governance?' Governance: An International Journal of Policy and Administration, vol 3, no 2, April, pp 205-14, doi.org/10.1111/j.14680491.1990.tb00116.x.

1991, 'A public management for all seasons?', Public Administration, vol 69, no 1, March, pp 3-19, doi.org/10.1111/j.1467-9299.1991.tb00779.x.

Joint Committee of Public Accounts and Audit Committee 2002, Review of the Accrual Budget Documentation, www.aphref.aph.gov.au_house_committee_ jcpaa_accrualbudget_chapter1.pdf.

Nethercote, J 1999, Departmental Machinery of Government since 1987, Research Paper 24 1998-99, Politics and Public Administration Group, Parliamentary Library Research, Australian Parliament House, Jun, www.aph.gov.au/About_ Parliament/Parliamentary_Departments/Parliamentary_Library/pubs/rp/ rp9899/99RP24.

Osborne, SP 2006, 'The new public governance?', Public Management Review, vol 18, no 3, doi.org/10.1080/14719030600853022. 
Parliamentary Joint Committee on the Australian Commission for Law Enforcement Integrity 2014, Official Committee Hansard, Commonwealth of Australia, 26 Sep, parlinfo.aph.gov.au/parlInfo/search/display/display. w3p;db=COMMITTEES;id=committees/commjnt/5006a599-6dd7-4ac0a69f-49b317ca84af/0003;query=Id:\%22committees/commjnt/5006a5996dd7-4ac0-a69f-49b317ca84af/0011\%22.

Public Service Act 1999, Federal Register of Legislation, www.legislation.gov.au/ Details/C2017C00270.

Rhodes, RA 1997, Understanding Governance: Policy Networks, Governance, Reflexivity and Accountability, Open University Press, Philadelphia.

Uhrig, J 2003, 'Executive summary', Review of the Corporate Governance of Statutory Authorities and Office Holders, Commonwealth of Australia, Jun, p 1, nla.gov. au/nla.obj-922761191/view?partId=nla.obj-924528151\#page/n8/mode/1up. 
This text is taken from Designing Governance Structures for Performance and Accountability: Developments in Australia and Greater China, edited by Andrew Podger, Tsai-tsu Su, John Wanna, Hon S. Chan and Meili Niu, published 2020 by ANU Press, The Australian National University, Canberra, Australia. 